\title{
SEC14L1 wt Allele
}

National Cancer Institute

\section{Source}

National Cancer Institute. SEC14L1 wt Allele. NCI Thesaurus. Code C111870.

Human SEC14L1 wild-type allele is located in the vicinity of 17q25.2 and is approximately $130 \mathrm{~kb}$ in length. This allele, which encodes SEC14-like protein 1, may play a role in intracellular transport. Aberrant elevated expression of the gene may be associated with a poor prognosis for prostate adenocarcinoma. 